\title{
Pengaruh Fertilitas \\ Terhadap Partisipasi Tenaga Kerja Perempuan
}

\author{
Andri Harsoyo ${ }^{1}$ \\ Eny Sulistyaningrum ${ }^{2}$
}

\begin{abstract}
ABSTRAK
Indonesia seperti halnya negara-negara lain di dunia, mengalami tren penurunan pada tingkat fertilitas total dan tren kenaikan pada tingkat partisipasi angkatan kerja perempuan. Penelitian ini melihat pengaruh fertilitas perempuan terhadap penawaran kerja di Indonesia dengan menggunakan data IFLS dan teknik estimasi variabel instrumental (instrumental variable/ IV) yang pertama diperkenalkan oleh Angrist dan Evans (1996; 1998) yang dilakukan di Amerika Serikat. Penelitian ini menunjukkan bagaimana preferensi orang tua terkait dengan jenis kelamin anak yang berbeda sebagai identifikasi terhadap fertilitas terhadap partisipasi perempuan dalam pasar tenaga kerja. Hasil dari penelitian ini menunjukkan bahwa fertilitas dengan pendekatan jumlah anak yang dimiliki yang kemudian diinstrumenkan dengan melihat jenis kelamin anak tersebut mengakibatkan penurunan pada penawaran tenaga kerja perempuan. Besaran pengaruh pada kelompok usia kerja adalah terdapat penurunan partisipasi kerja sekitar 52-54 persen dan penurunan jam kerja keseluruhan sekitar 23 jam/ minggu.
\end{abstract}

Kata kunci: Partisipasi tenaga kerja perempuan, fertilitas, IFLS, instrumental variable

\begin{abstract}
ABTRACT
Indonesia, like other countries in the world, is experiencing a downward trend in the level of total fertility and an upward trend in female labor force participation rates. This study looks at the effect of female fertility on job offers in Indonesia using IFLS data and the instrumental variable (IV) estimation technique first introduced by Angrist and Evans $(1996 ; 1998)$ conducted in the United States. This study shows how parental preferences are related to the gender of different children as identification of fertility for women's participation in the labor market. The results of this study indicate that the fertility approach of the number of children who are then instructed by looking at the sex of the child results in a decrease in the supply of female labor. The magnitude of influence in the working age group is a decrease in work participation of around 52-54 percent and a decrease in overall working hours of around 23 hours / week.
\end{abstract}

Keywords: Women's labor participation, fertility, IFLS, instrumental variables

\section{Pendahuluan}

Salah satu permasalahan yang sering ditemui di negara-negara berkembang adalah masalah kependudukan, begitu pula dengan Indonesia. Berdasarkan data Badan Pusat Statistik (BPS), jumlah penduduk Indonesia pada tahun 2015 berjumlah 255,5 juta jiwa. Jumlah penduduk yang besar tersebut merupakan sumber daya yang potensial bagi pembangunan nasional, tetapi sering kali pertumbuhan penduduk yang pesat tidak diimbangi oleh penyediaan sarana prasarana yang memadai sehingga dapat menjadi beban bagi pembangunan.

Pengendalian pertumbuhan penduduk dapat 
Tabel 1 Perempuan Berumur 15 Tahun ke Atas yang Bekerja Selama Seminggu yang Lalu Menurut Status Pekerjaan Utama

\begin{tabular}{|c|c|c|c|c|c|c|}
\hline \multirow{3}{*}{$\begin{array}{c}\text { Status } \\
\text { pekerjaan } \\
\text { utama*) }\end{array}$} & \multicolumn{6}{|c|}{ Tahun } \\
\hline & \multicolumn{2}{|c|}{2014} & \multicolumn{2}{|c|}{2015} & \multicolumn{2}{|c|}{2016} \\
\hline & Jml. & $\%$ & Jml. & $\%$ & Jml. & $\%$ \\
\hline 1 & 7.851 .528 & 17,21 & 8.669 .575 & 18,28 & 8.137 .956 & 17,34 \\
\hline 2 & 4.950 .612 & 10,85 & 5.035 .303 & 10,62 & 6.365 .667 & 13,56 \\
\hline 3 & 768.538 & 1,68 & 844.267 & 1,78 & 787.123 & 1,68 \\
\hline 4 & 15.154 .975 & 33,21 & 16.447 .115 & 34,68 & 16.477 .957 & 35,11 \\
\hline 5 & 1.698 .355 & 3,72 & 1.981 .611 & 4,18 & 1.994 .270 & 4,25 \\
\hline 6 & 1.002 .141 & 2,20 & 1.013 .791 & 2,14 & 1.003 .194 & 2,14 \\
\hline 7 & 14.203 .592 & 31,13 & 13.430 .396 & 28,32 & 12.164 .760 & 25,92 \\
\hline Total & 45.629 .741 & 100,00 & 47.422 .058 & 100,00 & 46.930 .927 & 100,00 \\
\hline
\end{tabular}

Catatan: *) 1. Berusaha sendiri; 2. Berusaha dibantu buruh tidak tetap; 3. Berusaha dibantu buruh tetap/buruh dibayar; 4. Buruh/Karyawan/Pegawai; 5. Pekerja bebas di pertanian; 6. Pekerja bebas di non-pertanian; 7. Pekerja keluarga tak dibayar/Unpaid family worker

Sumber: Keadaan Angkatan Kerja di Indonesia Februari 2014-2016, BPS

dilakukan melalui upaya mengendalikan tingkat kelahiran seperti melalui program Keluarga Berencana $(\mathrm{KB})$ dengan tujuan untukmeningkatkan kesejahteraan ibu dan anak dalam mewujudkan keluarga kecil yang berkualitas. Terciptanya keluarga yang berkualitas tidak lepas dari peranan orang tua, terutama ibu sebagai salah satu pilar dalam keluarga. Pada umumnya, peran seorang ibu adalah bertanggung jawab dalam mengurus rumah tangga, tetapi akhir-akhir ini kenyataan menunjukkan bahwa perempuan sekarang tidak hanya berperan sebagai ibu rumah tangga. Tuntutan sosial dan ekonomi rumah tangga yang cukup berat mendorong perempuan untuk mencari nafkah bagi keluarganya (Dewi, 2012). Manning (1998 dalam (Ogawa \& Akter, 2007) menyatakan bahwa semakin tingginya tingkat pendidikan perempuan dan diikuti oleh menurunnya fertilitas, penundaan waktu pernikahan, akses yang mudah terhadap fasilitas penitipan anak, dan semakin fleksibelnya peraturan dalam bekerja adalah faktor-faktor yang membuat partisipasi perempuan dalam pasar tenaga kerja meningkat.

Indonesia seperti halnya negara-negara lain di dunia, mengalami tren penurunan pada tingkat fertilitas total dan tren kenaikan pada tingkat partisipasi angkatan kerja perempuan. Berdasarkan data BPS, tingkat fertilitas total di Indonesia pada tahun 1971 sebesar 5,61 dan kemudian menurun menjadi 2,60 di tahun 2012. Tingkat partisipasi
Gambar 1. Grafik Tingkat Partisipasi Angkatan Kerja (TPAK) Perempuan dan Total Fertility Rate (TFR), 1980-2012

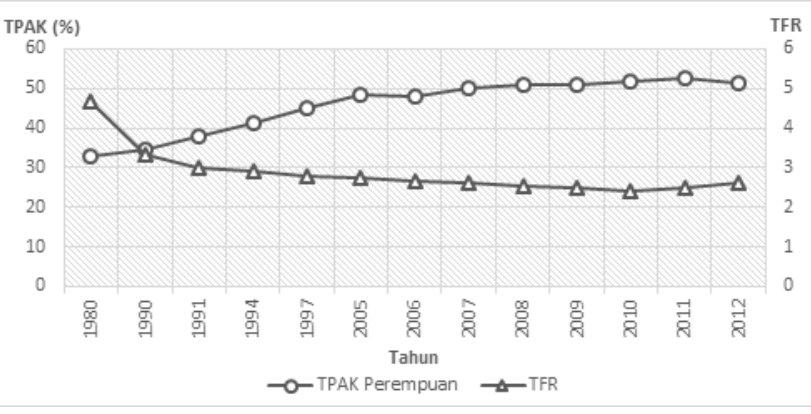

Sumber: BPS

tenaga kerja perempuan di Indonesia menurut hasil sensus penduduk tahun 1980 mencapai sekitar 33 persen dari seluruh angkatan kerja yang bekerja secara aktif (Hakim, 2011). Memasuki tahun 2000an, tingkat partisipasi tenaga kerja perempuan naik menjadi sekitar 50 persen. Dari data tersebut, dapat dilihat bahwa Indonesia mengalami tren penurunan pada tingkat fertilitas total dan tren kenaikan pada tingkat partisipasi angkatan kerja perempuan (lihat Gambar 1).

Angka partisipasi kerja yang meningkat tersebut ternyata belum tentu menggambarkan sesuatu yang menggembirakan. Data BPS dalam kurun waktu 2014-2016 menunjukkan bahwa terdapat lebih dari 25 persen pekerja perempuan yang menjadi pekerja keluarga yang tidak dibayar (unpaid family worker) yang sebagian besar bekerja di sektor pertanian dan perdagangan (lihat Tabel 1).

Dari total jumlah perempuan yang bekerja, 
Gambar 2. Persentase Perempuan Berumur 15 Tahun ke Atas yang Bekerja Paruh Waktu Selama Seminggu yang Lalu Menurut Jumlah Jam Kerja Seluruhnya

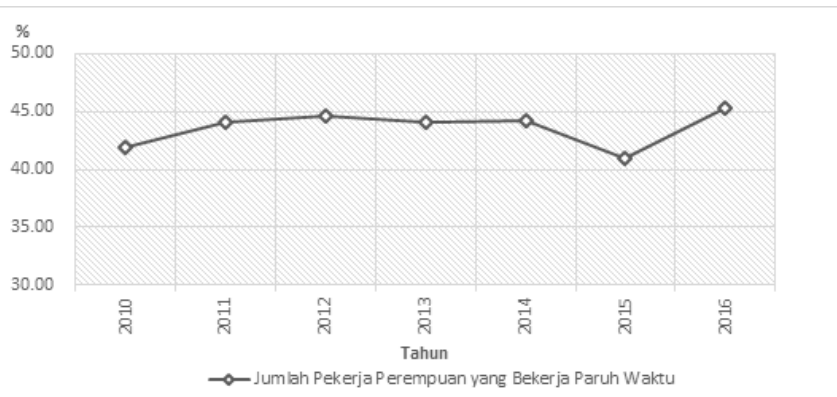

Sumber: Keadaan Angkatan Kerja di Indonesia Februari 2010-2016, BPS

sebanyak lebih dari 40 persen pekerja perempuan memilih untuk bekerja paruh waktu dalam periode tahun yang sama (lihat Gambar 2). Hal ini menunjukkan bahwa masih banyak perempuan yang memilih pekerjaan yang tidak banyak mengganggu perannya sebagai seorang ibu yang mengurus rumah tangga, termasuk merawat dan membesarkan anak-anaknya.

Penelitian ini merupakan replikasi model Angrist dan Evans (1996; 1998) yang menggunakan metode estimasi Instrumental Variable (IV). Perbedaan penelitian ini dengan penelitian-penelitian sebelumnya terletak pada lokasi, periode waktu, sumber dan struktur data yang digunakan, serta mengganti atau menambahkan variabel kontrol, seperti pendidikan, dan variabel demografi lainnya. Selain itu, penelitian ini hanya berfokus pada tenaga kerja perempuan pada usia kerja, seperti yang dilakukan oleh Cruces dan Galiani (2007) dan Daouli, et al. (2009).

Paper ini disajikan sebagai berikut. Pada bagian berikutnya akan dibahas teori dan literatur yang diacu dalam paper ini. Kemudian, bagian ketiga akan menyajikan sumber data dan metodologi yang digunakan. Pembahasan mengenai hasil estimasi dan pengujian setelah estimasi terangkum pada bagian keempat. Dan yang terakhir merupakan

Gambar 3 Diagram Ketenagakerjaan menurut BPS

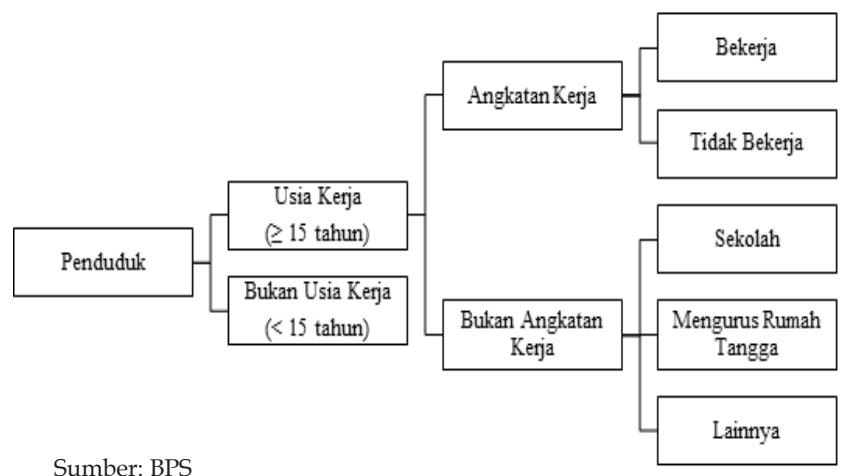

kesimpulan dan saran.

2. Landasan Teori

2.1 Konsep Ketenagakerjaan

Konsep dan definisi yang digunakan dalam penelitian ini mengacu pada konsep BPS dalam pengumpulan data ketenagakerjaan. Konsep tersebut terangkum pada Gambar 3. Selain itu, BPS juga mendefinisikan bekerja sebagai kegiatan ekonomi yang dilakukan oleh seseorang dengan maksud memperoleh atau membantu memperoleh pendapatan atau keuntungan, paling sedikit 1 jam (tidak terputus) dalam seminggu yang lalu. Kegiatan tersebut termasuk pula kegiatan pekerja tak dibayar yang membantu dalam suatu usaha/ kegiatan ekonomi. Namun, definisi bekerja dalam pasar kerja adalah bekerja untuk mendapatkan upah dan tidak termasuk kegiatan pekerja yang tidak dibayar, seperti pekerjaan rumah tangga yang sering dilakukan oleh perempuan (Brewster \& Rindfuss, 2000). Terdapat pula definisi mempunyai pekerjaan tetapi sementara tidak bekerja, yaitu keadaan dari seseorang yang mempunyai pekerjaan tetapi selama seminggu yang lalu sementara tidak bekerja karena berbagai sebab, seperti: sakit, cuti, menunggu panen, dan lain sebagainya.

\subsection{Teori Keputusan Bekerja}

Ehrenberg dan Smith (2012, hal. 165) menjelaskan bahwa keputusan dalam penawaran tenaga kerja dapat dibedakan menjadi dua kategori. Kategori pertama adalah yang terkait dengan keputusan apakah akan bekerja atau tidak, dan berapa lama waktu yang digunakan untuk bekerja jika memutuskan untuk bekerja. Kategori kedua adalah terkait dengan keputusan akan mencari jenis pekerjaan seperti apa dan lokasi tempat pekerjaan itu ditawarkan. Ehrenberg dan Smith (2012, hal. 170) juga menjelaskan bahwa keputusan untuk bekerja merupakan keputusan bagaimana seseorang akan menggunakan waktunya, yaitu pada pilihan-pilihan antara waktu yang digunakan untuk santai/tidak bekerja (leisure), bekerja di rumah (unpaid work) atau bekerja di pasar kerja untuk mendapatkan upah (paid work). Seringkali waktu luang/tidak bekerja (leisure) dianggap sebagai sisi lain dari penawaran tenaga kerja. Karena dilihat dari besarannya, waktu yang digunakan untuk waktu luang/tidak bekerja (leisure) adalah waktu yang tidak digunakan untuk bekerja, demikian juga sebaliknya. 
Pada umumnya ketika pendapatan seseorang naik, taraf kesejahteraan seseorang akan meningkat dan harga dari waktu luang/tidak bekerja (leisure) akan menjadi lebih murah sehingga orang tersebut cenderung akan menggunakan banyak waktunya untuk waktu luang/tidak bekerja (leisure). Terkait dengan preferensi, tentunya akan berbeda pada tiap-tiap individu dalam mengambil keputusan untuk bekerja. Preferensi tersebut dapat menjadi pendorong seseorang untuk bekerja atau tidak bekerja. Teori ini mengatakan bahwa jika pendapatan naik sementara tingkat upah dan preferensi dijaga tetap konstan, maka banyaknya waktu yang digunakan untuk waktu luang/tidak bekerja (leisure) akan meningkat. Dengan kata lain, jika pendapatan naik dan upah tetap konstan, dorongan untuk bekerja akan menurun, dan sebaliknya. Keadaan ini disebut sebagai income effect. Selain itu, ketika pendapatan konstan, peningkatan pada tingkat upah akan berdampak pada naiknya harga barang di pasar dan mengurangi kebutuhan akan waktu luang/tidak bekerja (leisure), sehingga menambah dorongan untuk bekerja, begitu pula sebaliknya. Keadaan seperti ini disebut dengan substitution effect. Efek ini terjadi karena harga dari waktu luang/tidak bekerja (leisure) berubah di mana pendapatan tetap konstan, maka waktu luang/tidak bekerja (leisure) dan waktu untuk bekerja akan saling mensubstitusi satu sama lain.

\subsection{Partisipasi Tenaga Kerja Perempuan}

Berdasarkan teori alokasi waktu yang dikembangkan oleh Becker (1965) dan Gronau (1976), setiap rumah tangga akan berusaha untuk memaksimalkan kepuasan (utility) yang ditentukan oleh alokasi waktu setiap individu dalam rumah tangga untuk bekerja di rumah, bekerja di pasar kerja, atau tidak bekerja (leisure). Dalam teori produksi rumah tangga (household production), keputusan partisipasi individu, terutama perempuan dalam angkatan kerja merupakan hasil dari pembuatan keputusan bersama dalam rumah tangga dan alokasi waktunya tergantung dari karakteristik rumah tangga, seperti jumlah anak, luas rumah, dan lain sebagainya. Selain itu, utilitas yang ada tidak hanya meliputi waktu luang/tidak bekerja (leisure) dan bekerja untuk mendapatkan upah, tetapi juga waktu untuk melakukan pekerjaan rumah (unpaid work). Pekerjaan-pekerjaan rumah
Gambar 4 TPAK Menurut Jenis Kelamin Tahun 2005-2015

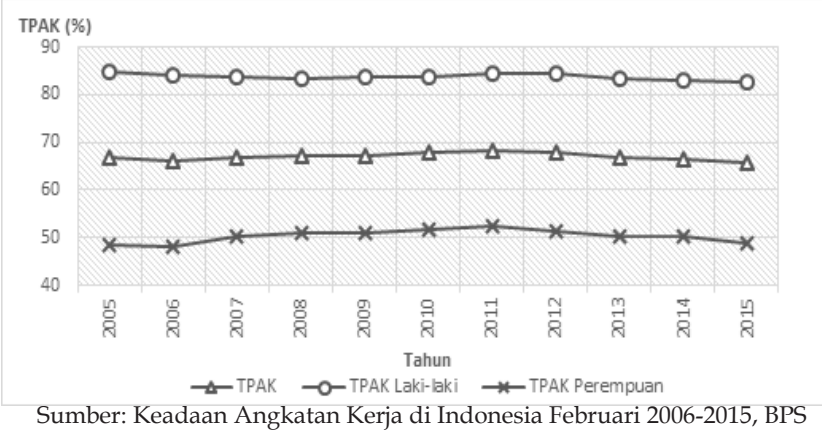

tangga masih merupakan kegiatan yang biasa dilakukan oleh perempuan, sehingga keputusan untuk bekerja tidak saja dipengaruhi oleh faktor upah dan jam kerja, tetapi juga dipengaruhi oleh opportunity cost dari waktu di rumah (household time).

Secara agregasi, besarnya angkatan kerja perempuan dapat diukur dengan tingkat partisipasi kerja perempuan, yaitu proporsi populasi perempuan pada usia kerja (di antara usia 15 sampai dengan 64 tahun) yang sedang bekerja atau mencari pekerjaan untuk mendapatkan upah. Tingkat partisipasi tenaga kerja perempuan di Indonesia mengalami peningkatan menjadi sekitar 50 persen memasuki tahun 2000-an sampai sekarang, seperti yang terlihat pada Gambar 4.

Peningkatan tersebut disebabkan oleh dua faktor utama yaitu dari sisi penawaran dan permintaan (Tjiptoherijanto, 1997 dalam (Tjaja, 2000). Dari sisi penawaran, peningkatan tersebut disebabkan oleh tingkat pendidikan perempuan yang semakin membaik disertai menurunnya angka kelahiran. Dari sisi permintaan, perkembangan perekonomian dari sisi produksi memerlukan tenaga kerja perempuan seperti industri tekstil. Di sisi lain makin meningkatnya kebutuhan hidup juga ikut mendorong perempuan untuk membantu perekonomian keluarga.

Di Indonesia, partisipasi tenaga kerja perempuan dipengaruhi oleh faktor sosio-demografi, ekonomi dan budaya (Widarti, 1998). Sobol (1963 dalam(Widarti, 1998) menunjukkan bahwa terdapat tiga kondisi perempuan memasuki pasar tenaga kerja, yaitu kondisi yang memungkinkan (enabling condition), seperti jumlah dan usia anak, kondisi yang memfasilitasi (facilitating condition), seperti pendidikan atau pelatihan, pengalaman kerja, dan kondisi pasar tenaga kerja lokal, serta kondisi yang mencetuskan (precipitating condition), seperti ketidakpuasan terhadap penghasilan 
keluarga dan ketidakpuasan personal.

\subsection{Fertilitas}

Brewster dan Rindfuss (2000) menyatakan bahwa fertilitas secara sederhana diartikan sebagai kemampuan menghasilkan keturunan atau kelahiran hidup dan secara biologis terbatas pada perempuan usia subur. Namun, fertilitas tidak hanya terbatas pada menghasilkan keturunan (childbearing), tetapi juga merawat dan mengasuh anak (childrearing) sampai dewasa. Hal itulah yang memicu hubungan negatif antara fertilitas dan partisipasi tenaga kerja perempuan (Bernhardt, 1993 dalam(Brewster \& Rindfuss, 2000). Menurut Becker (1960), seorang anak dilihat dari sisi ekonomi dapat dianggap sebagai barang konsumsi (a consumption good, consumer's durable) yang memberikan suatu kepuasan (utility) tertentu bagi orang tua. Secara ekonomi, fertilitas dipengaruhi oleh pendapatan keluarga, biaya memiliki anak dan selera.

Penelitian dari Angrist dan Evans (1998) menggunakan komposisi jenis kelamin anak sebagai instrumen dari fertilitas. Ide yang diusung dalam penelitian tersebut adalah apabila diasumsikan seorang ibu yang memiliki lebih dari satu anak dan ingin memutuskan berapa jumlah anak yang ingin dimiliki, maka ibu tersebut akan lebih memilih untuk memiliki anak dengan komposisi jenis kelamin yang berbeda. Hal ini membuat komposisi anak dengan jenis kelamin yang sama akan mengurangi utilitas dari jumlah anak yang dimiliki, dan untuk mengimbanginya, maka ibu tersebut akan cenderung berpeluang untuk menambah anak.

Secara agregasi, fertilitas diukur dengan menggunakan Total Fertility Rate (TFR), yaitu rata-rata anak yang dilahirkan perempuan hingga berakhir masa reproduksi (Brewster dan Rindfuss, 2000; Badan Pusat Statistik, 2015). Berdasarkan data BPS, tingkat fertilitas total di Indonesia pada tahun 1971 berada pada angka 5,61 dan menurun tajam menjadi 2,85 di tahun 1994. Kemudian angka tersebut turun lagi menjadi 2,6 pada tahun 2003 dan stagnan pada tahun-tahun berikutnya (lihat Gambar 5).

\subsection{Hubungan Fertilitas dan Partisipasi Tenaga} Kerja Perempuan

Pengaruh dari fertilitas terhadap partisipasi tenaga kerja perempuan telah menjadi topik yang
Gambar 5 Total Fertility Rate (TFR) di Indonesia, 1971-201

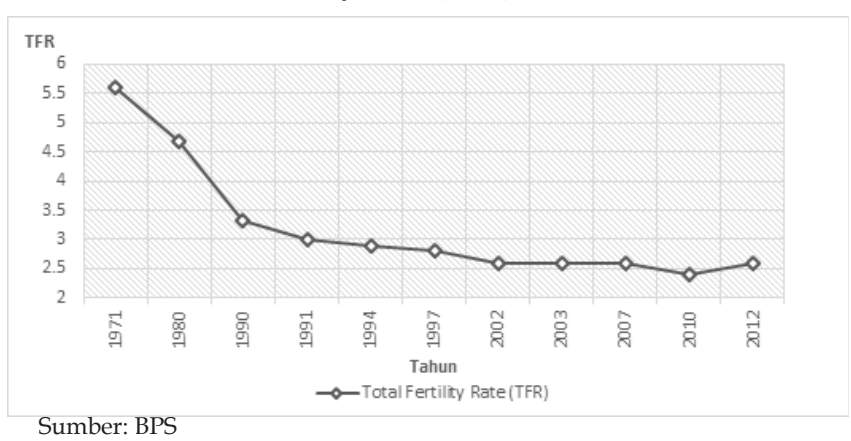

banyak diteliti di dunia. Penelitian yang dilakukan oleh Angrist dan Evans (1996; 1998) di Amerika Serikat, Cruces dan Galiani (2007) di Argentina dan Meksiko, dan Daouli, et al. (2009) di Yunani menunjukkan bahwa terdapat hubungan negatif antara fertilitas dan partisipasi tenaga kerja perempuan. Penelitian tersebut menggunakan konstruksi model yang dikembangkan oleh Angrist dan Evans (1996; 1998), di mana fertilitas menjadi variabel instrumen yang menggunakan preferensi orang tua terhadap komposisi jenis kelamin anak.

Angrist dan Evans (1998) menyatakan bahwa penawaran tenaga kerja yang terkait dengan kemampuan menghasilkan keturunan diperumit dengan sifat endogen dari fertilitas. Selain itu, pada beberapa penelitian ditemukan fakta bahwa di antara fertilitas dan partisipasi tenaga kerja perempuan terdapat hubungan kausalitas dua arah (e.g.(Cramer, 1980; Engelhardt, Kogel, \& Prskawetz, 2004; Mishra \& Smyth, 2010). Model penelitian ini kemudian diacu oleh Cruces dan Galiani (2007) di Argentina dan Meksiko, dan Daouli, et al. (2009) di Yunani.

Disamping itu, acuan lain dalam penelitian ini adalah hasil penelitian yang dilakukan oleh Lee dan McElwain (1985). Penelitian tersebut menunjukkan bahwa hubungan partisipasi tenaga kerja perempuan di Korea dan fertilitas adalah negatif dan lemah. Selain itu, urbanisasi juga dapat menurunkan fertilitas dengan cara menunda usia pernikahan. Begitu pula dengan penggunaan alat kontrasepsi yang dapat menurunkan fertilitas. Hasil yang hampir serupa juga ditemukan dalam penelitian Lavy dan Zablotsky (2011) yang dilakukan di Israel. Gregory (1982) dan Bloom, et al. (2009) juga menemukan bahwa penawaran pekerja perempuan diperlambat oleh fertilitas. Bloom, et al. (2009) menggunakan perubahan pada peraturan terkait dengan aborsi sebagai instrumen dari fertilitas. 
Tabel 2 Ringkasan variabel yang digunakan dalam model Instrumental Variable (IV)

\begin{tabular}{|c|c|c|}
\hline Kelompolk & Variabel & Keterangan \\
\hline \multirow[t]{2}{*}{$\begin{array}{l}\text { Variabel } \\
\text { dependen }\end{array}$} & awork4pqy & $\begin{array}{l}\text { Dwowy vaviable } \\
\text { dwork4pay=1, jika angkatan kerja } \\
\text { dwork4pay }=0 \text {, jika bukan angkatan kerja (BAK) }\end{array}$ \\
\hline & workhow & numerik \\
\hline \multirow[t]{8}{*}{ Variabel kcontrol } & $a g e$ & numerik \\
\hline & agelstbirth & numerik \\
\hline & dimar & $\begin{array}{l}\text { Dwmmy variable } \\
\text { dmarr }=1 \text {, jika menikah } \\
\text { dmarr }=0 \text {, jika selain itu }\end{array}$ \\
\hline & educyr & numerik \\
\hline & spoeducyr & numerik \\
\hline & inspoincpermith & numerik \\
\hline & diana & $\begin{array}{l}\text { Duwny variable } \\
\text { djava=1, jika tinggal di Pulau Jawa } \\
\text { djava }=0 \text {, jika selain itu }\end{array}$ \\
\hline & dwban & $\begin{array}{l}\text { Dumoyy variable } \\
\text { durban }=1, \text { jika perkotaan } \\
\text { durban }=0, \text { jika perdesaan }\end{array}$ \\
\hline $\begin{array}{l}\text { Variabel yg di- } \\
\text { instrumenkan }\end{array}$ & dmore2child & $\begin{array}{l}\text { Dwowy variable } \\
\text { dmore } 2 \text { child }=1 \text {, jika memiliki }>2 \text { anak } \\
\text { dmore } 2 \text { child }=0 \text {, jika selain itu }\end{array}$ \\
\hline \multirow[t]{3}{*}{$\begin{array}{l}\text { Variabel } \\
\text { instrumen }\end{array}$} & dsanegender & $\begin{array}{l}\text { Dwony variable } \\
\text { dgamegender }=1 \text {, jika memiliki } 2 \text { anak pertama dengan } \\
\text { jenis kelamin yang gama } \\
\text { dgamegender }=0 \text {, jika selain itu }\end{array}$ \\
\hline & atwoboys & $\begin{array}{l}\text { Dwowy variable } \\
\text { dtwoboyg=1, jika memiliki } 2 \text { anak pertama dengan jenis } \\
\text { kelamin laki-laki } \\
\text { dtwoboyg }=0 \text {, jika gelain itu }\end{array}$ \\
\hline & dinogirls & $\begin{array}{l}\text { Dwony vaviable } \\
\text { dtwogirls }=1 \text {, jika memiliki } 2 \text { anak pertama dengan jenis } \\
\text { kelamin perempuan } \\
\text { dtwogirlg }=0 \text {, jika gelain itu }\end{array}$ \\
\hline
\end{tabular}

sumbec Data IFL5-4 dan,IFLS-5 (data diolal)

Sedangkan menurut hasil penelitian yang dilakukan oleh Yamada dan Yamada (1984) dengan membedakan perempuan yang menikah dan bekerja paruh waktu dari yang bekerja penuh, ditemukan bahwa koefisien struktural dari penawaran tenaga kerja paruh waktu yang berbeda secara signifikan dari penawaran tenaga kerja penuh dalam hal elastisitas. Selain itu, ditemukan juga interdependensi antara keputusan perempuan yang sudah menikah untuk bekerja sebagai karyawan paruh waktu dengan fertilitas di kotakota di Jepang.

Hasil yang berbeda ditunjukkan oleh penelitian Aguero dan Marks (2008). Penelitian tersebut menunjukkan bahwa memiliki anak bukanlah penghalang untuk bekerja dan mendapatkan upah bagi perempuan di kawasan Amerika Latin. Begitu pula dengan penelitian yang dilakukan Siah dan Lee (2015) di Malaysia, di mana tidak ditemukan adanya bukti bahwa kehadiran anak dapat menghambat perempuan untuk kembali dan meneruskan untuk bekerja. Selain itu, keputusan seorang perempuan untuk memiliki keturunan tidak dipengaruhi oleh kondisi pekerjaan.

3. Metode Penelitian

3.1 Metode Pengumpulan Data

Penelitian ini akan menggunakan data Indonesian 
Tabel 3 Perkembangan Variabel Utama yang Digunakan pada Penelitian Ini 車

\begin{tabular}{lccc} 
& Variabel & \multicolumn{2}{c}{ Nilai rata-rata } \\
\hline \multirow{2}{*}{ Tahun survei } & IFLS4 & IFLS5 \\
& & 2007 & 2014
\end{tabular}

\section{Fertilitas}

Jumlah anak yang dilahirkan

1,7457 1,5043

Penawaran tenaga kerja perempuan

Partisipasi kerja perempuan

0,3986

0,4045

Jam kerja keseluruhan

14,2016

14,4959

Persentase bekerja paruh waktu $(<35$

76,52

76,99 jam/minggu)

Sumber: Hasil olahan dengan data IFLS4 dan IFLS5

Tabel 4 Pengukuran Fertilitas dan Penawaran Tenaga Kerja Perempuan

\begin{tabular}{lrr}
\hline \multicolumn{1}{c}{ Sampel data } & \multicolumn{1}{c}{$\begin{array}{c}\text { IFLS4 } \\
\text { IFLS5 } \\
\text { Semua perempuan usia kerja }\end{array}$} & \multicolumn{2}{c}{$\mathbf{2 0 1 4}$} \\
\hline Rerata jumlah anak yang dilahirkan & 1,75 & 1,50 \\
Persentase memiliki 2 anak atau lebih & 47,55 & 39,04 \\
Persentase bekerja selama seminggu yang lalu & 39,86 & 40,45 \\
Jumlah observasi & 8.145 & 8.863 \\
\hline Perempuan usia kerja dengan 2 anak atau lebih & & \\
Rerata jumlah anak yang dilahirkan & 2,80 & 2,56 \\
Persentase memiliki lebih dari 2 anak & 42,99 & 34,60 \\
Persentase bekerja selama seminggu yang lalu & 40,48 & 40,59 \\
Jumlah observasi & 3.873 & 3.460 \\
\hline
\end{tabular}

\section{Sumber: Hasil olahan dengan data IFLS4 dan IFLS5}

Family Life Survey (IFLS) gelombang keempat (2007) dan kelima (2014), di mana data tersebut akan dianalisis dalam struktur data pooled crosssection. Alasan penggunaan data IFLS adalah seluruh komponen data yang diperlukan dalam penelitian ini tersedia dalam cakupan data IFLS. Keseluruhan data tersebut mencakup data-data indikator dari seluruh variabel dalam model yang digunakan dalam penelitian ini.

\subsection{Instrumen Penelitian}

Berdasarkan beberapa penelitian terdahulu, diketahui bahwa terdapat hubungan simultan/ kausalitas dua arah antara fertilitas dan partisipasi tenaga kerja perempuan (e.g.(Cramer, 1980; Engelhardt, Kogel, \& Prskawetz, 2004; Mishra \& Smyth, 2010). Hal ini sesuai dengan apa yang disampaikan oleh Angrist dan Evans (1998) bahwa penawaran tenaga kerja yang terkait dengan kemampuan menghasilkan keturunan (childbearing) diperumit dengan sifat endogen dari fertilitas. Oleh karena itu, alat analisis yang digunakan dalam penelitian ini adalah Instrumental Variable (IV) dengan pendekatan Two-Stage Least Squares (2SLS).

3.3 Metode Analisis Data

Penelitian ini menggunakan replikasi dari model yang terdapat pada penelitian Angrist dan Evans (1996; 1998). Adapun model penelitian struktural yang digunakan adalah:

$y_{i}=\alpha_{0}+\alpha_{1} w_{i}+\alpha_{2} x_{i}+\varepsilon_{i}$

di mana $y_{i}$ adalah penawaran tenaga kerja dengan pendekatan partisipasi dalam angkatan kerja (bekerja atau tidak) dan variabel jam kerja dalam 
Tabel 5 Ringkasan Statistik dari Variabel yang Digunakan

\begin{tabular}{|c|c|c|c|c|c|c|}
\hline \multirow[b]{2}{*}{ Variabel } & \multicolumn{6}{|c|}{ Statistik deskriptif data } \\
\hline & $\begin{array}{l}\text { Jml. } \\
\text { Obs. }\end{array}$ & Rerata & $\begin{array}{l}\text { Standar } \\
\text { deviasi }\end{array}$ & $\begin{array}{l}\text { Nilai } \\
\text { min. }\end{array}$ & $\begin{array}{l}\text { Nilai } \\
\text { maks. }\end{array}$ & Satuan \\
\hline dwork $4 p a y$ & 29.553 & 0,4289 & 0,4949 & 0 & 1 & dummy \\
\hline workhour & 26.222 & 15,0763 & 18,4299 & 0 & 54 & $\mathrm{jam} / \mathrm{ming} \mathrm{gu}$ \\
\hline dmore2child & 17.008 & 0,1683 & 0,3741 & 0 & 1 & dummy \\
\hline dtwoboys & 13.538 & 0,0969 & 0,2958 & 0 & 1 & dummy \\
\hline dtwogirls & 13.538 & 0,0872 & 0,2822 & 0 & 1 & dummy \\
\hline dsamegender & 13.539 & 0,1841 & 0,3876 & 0 & 1 & dummy \\
\hline age & 44.754 & 34,6693 & 12,8580 & 15 & 64 & tahun \\
\hline agelstbirth & 13.520 & 25,0590 & 5,9709 & 11 & 55 & tahun \\
\hline dmarr & 42.986 & 0,7193 & 0,4493 & 0 & 1 & dummy \\
\hline educyr & 28.227 & 8,9335 & 4,0117 & 0 & 22 & tahun \\
\hline spoeducyr & 18.904 & 8,8723 & 4,1627 & 0 & 22 & tahun \\
\hline Inspoincpermth & 10.253 & 13,9035 & 0,9940 & 8,9227 & 20,7233 & - \\
\hline djava & 44.754 & 0,5519 & 0,4973 & 0 & 1 & dummy \\
\hline durban & 44.754 & 0,5777 & 0,4939 & 0 & 1 & dummy \\
\hline
\end{tabular}

Sumber: Hasil olahan dengan data IFLS4 dan IFLS5

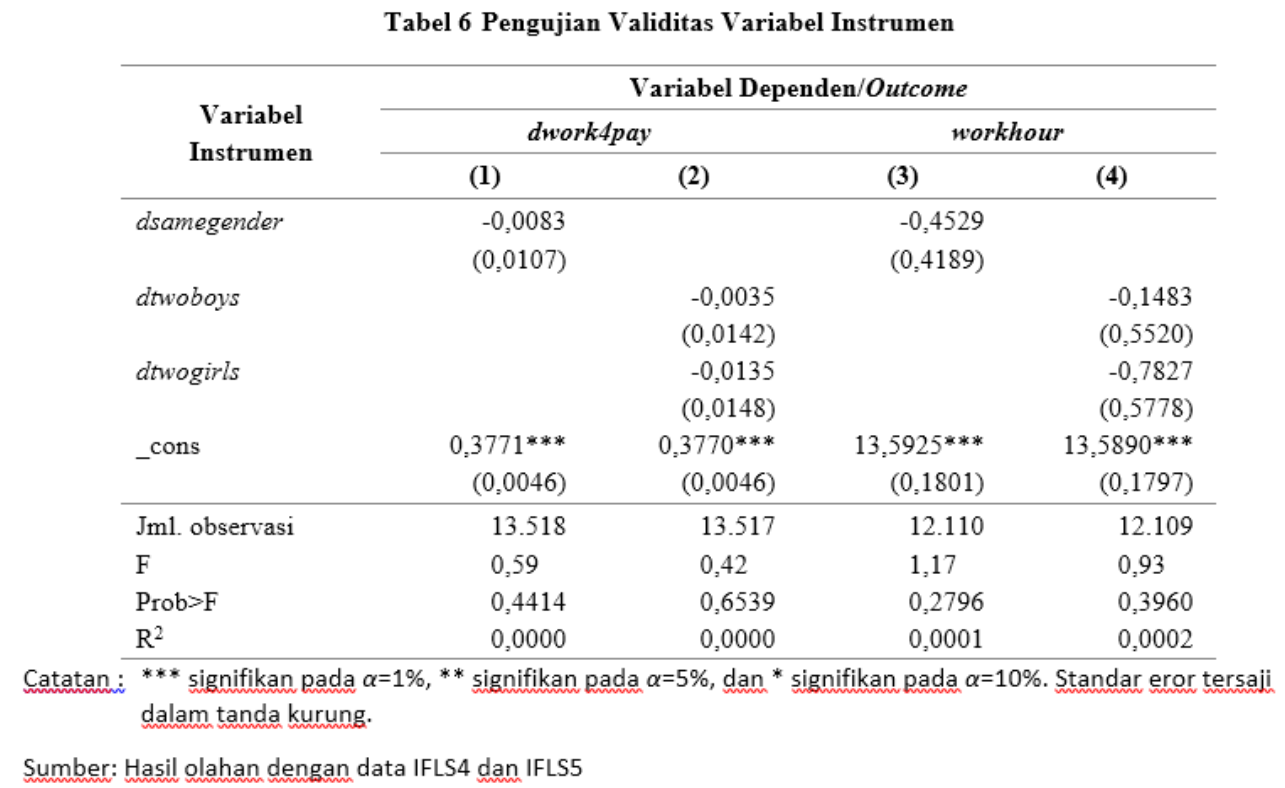

seminggu, $x_{i}$ adalah fertilitas yang bersifat endogen dengan pendekatan memiliki lebih dari dua anak, dan $w_{i}$ adalah variabel kontrol berupa usia, usia pada saat pertama kali melahirkan, tingkat pendidikan responden dan suami, pendapatan suami serta karakteristik tempat tinggal.

Model penelitian first stage yang digunakan adalah:

$x_{i}=\beta_{0}+\beta_{1} w_{i}+\beta_{2}\left(\right.$ dsamegender $\left._{i}\right)+u_{i}$

penggunaan variabel instrumen dsamegender $_{i}$ dapat lebih diperinci dengan memisahkan berdasarkan jenis kelamin, sehingga menghasilkan alternatif model lain yang bersifat overidentified (Angrist \& Evans, 1996; 1998) adalah:

$x_{i}=\beta_{0}+\beta_{1} w_{i}+\beta_{2}\left(d t w o b o y s_{i}\right)+\beta_{3}\left(d_{t w o g i r l s}\right)+u_{i} \ldots .(3)$

di mana dsamegender ${ }_{i}$ adalah kelahiran anak pertama dan kedua dengan jenis kelamin yang sama, dtwoboys adalah kelahiran anak pertama dan kedua dengan jenis kelamin laki-laki, dan $d$ twogirls $_{i}$ adalah kelahiran anak pertama dan kedua dengan jenis kelamin perempuan. Adapun penjelasan tentang variabel-variabel yang digunakan dalam penelitian ini dapat dilihat pada Tabel 2. 
Tabel 7 Regresi Variabel yang Diinstrumenkan (Füst Stage Regression)

\begin{tabular}{|c|c|c|c|c|}
\hline \multirow{2}{*}{$\begin{array}{c}\text { Variabel } \\
\text { Independen }\end{array}$} & \multicolumn{4}{|c|}{ Variabel Dependen (dmore2child) } \\
\hline & (1) & (2) & (3) & (4) \\
\hline Outcome & \multicolumn{2}{|c|}{ dwork4pay } & \multicolumn{2}{|c|}{ workhour } \\
\hline \multirow[t]{2}{*}{ dsamegender } & $0,1315^{* 4+4}$ & & $0,1288 * 44$ & \\
\hline & $(0,0146)$ & & $(0,0150)$ & \\
\hline \multirow[t]{2}{*}{ atwoboys } & & $0,1595^{4+4}$ & & $0,1543^{4+4}$ \\
\hline & & $(0,0199)$ & & $(0,0204)$ \\
\hline \multirow[t]{2}{*}{ atwogirls } & & 0,1019444 & & $0,1016^{4+4}$ \\
\hline & & $(0,0191)$ & & $(0,0199)$ \\
\hline \multirow[t]{2}{*}{ age } & 0,0229444 & 0,0229444 & $0,0233^{444}$ & $0,0232^{4+4}$ \\
\hline & $(0,0011)$ & $(0,0011)$ & $(0,0011)$ & $(0,0011)$ \\
\hline \multirow[t]{2}{*}{ agelstbirth } & $-0,0183^{444}$ & $-0,0183^{4+4}$ & $-0,0186^{4+4}$ & $-0,0186^{4+4}$ \\
\hline & $(0,0013)$ & $(0,0013)$ & $(0,0014)$ & $(0,0014)$ \\
\hline \multirow[t]{2}{*}{ dmarr } & $-0,3939444$ & $-0,3659444$ & $-0,3897444$ & $-0,3642^{4+4}$ \\
\hline & $(0,0205)$ & $(0,0241)$ & $(0,0214)$ & $(0,0249)$ \\
\hline \multirow[t]{2}{*}{ educyr } & $-0,0014$ & $-0,0013$ & $-0,0010$ & $-0,0010$ \\
\hline & $(0,0015)$ & $(0,0015)$ & $(0,0016)$ & $(0,0016)$ \\
\hline \multirow[t]{2}{*}{ spoeducyr } & $-0,0023$ & $-0,0023$ & $-0,0030 * 4$ & $-0,0031^{4+}$ \\
\hline & $(0,0016)$ & $(0,0015)$ & $(0,0015)$ & $(0,0015)$ \\
\hline \multirow[t]{2}{*}{ inspoincpermth } & $-0,0121^{4+4}$ & $-0,0121^{4+4}$ & $-0,0106^{44}$ & $-0,0105^{4+4}$ \\
\hline & $(0,0046)$ & $(0,0046)$ & $(0,0047)$ & $(0,0047)$ \\
\hline \multirow[t]{2}{*}{ diana } & $-0,0338^{4+4}$ & $-0,0340^{4 * 4}$ & $-0,0284 * 4 *$ & $-0,0287^{4+4}$ \\
\hline & $(0,0079)$ & $(0,0079)$ & $(0,0082)$ & $(0,0082)$ \\
\hline \multirow[t]{2}{*}{$a w b a n$} & $-0,0027$ & $-0,0028$ & $-0,0052$ & $-0,0054$ \\
\hline & $(0,0085)$ & $(0,0085)$ & $(0,0088)$ & $(0,0088)$ \\
\hline \multirow[t]{2}{*}{ _cons } & 0,4839444 & $0,4568+44$ & $0,4607^{4+4}$ & $0,4351^{4+4}$ \\
\hline & $(0,0612)$ & $(0,0627)$ & $(0,0624)$ & $(0,0637)$ \\
\hline Jml. observasi & 6.333 & 6.333 & 5.822 & 5.822 \\
\hline $\mathrm{F}$ & $11.205,41$ & $10.093,13$ & $10.607,54$ & $9.557,66$ \\
\hline Prob $>F$ & 0,0000 & 0,0000 & 0,0000 & 0,0000 \\
\hline $\mathrm{R}^{2}$ & 0,3016 & 0,3027 & 0,3013 & 0,3022 \\
\hline
\end{tabular}

symber Hasil glahan dengan data IFLS4 dan IFLS5

4. Analisis

4.1 Deskripsi Data

Penelitian ini menggunakan data dari IFLS4 tahun 2007 dan IFLS5 tahun 2014 dalam struktur data pooled cross-section. Perkembangan dari variabel-variabel utama antara lain rata-rata jumlah anak yang dilahirkan mengalami penurunan dan partisipasi kerja dari perempuan mengalami peningkatan (lihat Tabel 3). Jam kerja secara keseluruhan pun mengalami kenaikan, tetapi persentase jumlah perempuan yang bekerja paruh waktu meningkat. Hal ini menunjukkan bahwa perempuan masih rentan mengurangi jam kerjanya untuk digunakan baik sebagai waktu luang (leisure) atau waktu untuk bekerja di rumah (unpaid work), seperti mengurus anak, membersihkan rumah, dan pekerjaan rumah lainnya.

Dalam penelitian ini, fertilitas dilihat dengan indikator apakah seorang perempuan memiliki lebih dari dua anak. Tabel 4 memperlihatkan partisipasi kerja dan persentase dari adanya tambahan anak yang dilahirkan. Untuk sampel data dari semua perempuan pada tahun 2007, sebanyak 47,55 persen perempuan memiliki dua anak atau lebih dan sebanyak 42,99 persen perempuan dengan dua anak memiliki anak ketiga. Untuk tahun 2014, jumlah tersebut menurun menjadi 39,04 persen untuk perempuan memiliki dua anak atau lebih dan 34,60 persen untuk perempuan dengan dua anak yang memiliki anak lagi. Untuk partisipasi kerja dari perempuan, sampel data 
Tabel 8 Hasil Pengujian setelah Estimasi IV

\begin{tabular}{|c|c|c|c|c|}
\hline \multirow{2}{*}{$\begin{array}{l}\text { Hasil pengujian } \\
\text { instrumen }\end{array}$} & \multicolumn{4}{|c|}{ Model Regresi } \\
\hline & (1) & (2) & (3) & (4) \\
\hline Variabel dependen & \multicolumn{2}{|c|}{ dworktpay } & \multicolumn{2}{|c|}{ workhowr } \\
\hline Variabel instrumen & dranegender & $\begin{array}{l}\text { dwobovys, } \\
\text { atwogivls }\end{array}$ & dsanegender & $\begin{array}{l}\text { dwoboys, } \\
\text { diwogivls }\end{array}$ \\
\hline Endogenitas & \multicolumn{4}{|c|}{ Robust regression $F$} \\
\hline F & 12,9817 & 12,5729 & 16,3427 & 15,7925 \\
\hline p-value & 0,0003 & 0,0004 & 0,0001 & 0,0001 \\
\hline Weak identification test & \multicolumn{4}{|c|}{ Kleibergen-Paap Waid rk F statistic } \\
\hline $\mathrm{F}$ & 81,6242 & 42,2784 & 73,3424 & 37,8872 \\
\hline \multicolumn{5}{|c|}{ Stock-Yogo Weak ID test critical values } \\
\hline $10 \%$ maximal $I V$ size & 16,38 & 19,93 & 16,38 & 19,93 \\
\hline $15 \%$ maximal $I V$ size & 8,96 & 11,59 & 8,96 & 11,59 \\
\hline $20 \%$ maximal $I V$ size & 6,66 & 8,75 & 6,66 & 8,75 \\
\hline $25 \%$ maximal $I V$ size & 5,53 & 7,25 & 5,53 & 7,25 \\
\hline Underindentiffication & \multicolumn{4}{|c|}{ Kleibergen-Paap ri LM statistic } \\
\hline Chi-sq & 78,497 & 80,403 & 70,716 & 72,442 \\
\hline p-value & 0,0000 & 0,0000 & 0,0000 & 0,0000 \\
\hline Overindentification & \multicolumn{4}{|c|}{ Hansen J statistic } \\
\hline Chi-9q & 0,000 & 0,4064 & 0,000 & 0,4490 \\
\hline p-value & $\begin{array}{l}\text { equation } \\
\text { exactly } \\
\text { identified }\end{array}$ & 0,5238 & $\begin{array}{l}\text { equation } \\
\text { exactiy } \\
\text { identified }\end{array}$ & 0,5028 \\
\hline
\end{tabular}

\begin{tabular}{lcccc}
\hline IV Heteroskedasticity test & Pagan-Hall general test statistic) \\
Chi-sq & 44,669 & 48,132 & 32,941 & 33,819 \\
p-value & 0,0000 & 0,0000 & 0,0000 & 0,0000 \\
\hline Instrumented & $:$ & \multicolumn{5}{c}{ dmore2child }
\end{tabular}

Inciuded instruments : $\quad$ age, agelstbirth, dmarr, educyr, diana durban

Exciuded instruments : asamegender dwoboys, dsanegender dwoboys,

atwogirls atwogivls

Gatatan: Pada variabel dependen workhour dilakukan robust stondard error karena terdapat percoasalahala heterorkedastisitas.

\section{Symber: Hasil glahan dengan data IFLS4 dan IFLS5}

masih menunjukkan penurunan persentase, serupa dengan data pada Tabel 3.

Untuk ringkasan statistik dari variabel instrumen, variabel kontrol, dan variabel dependen dalam struktur data pooled cross-section dapat dilihat pada Tabel 5. Variabel dependen workhour diset bernilai nol untuk responden yang tidak bekerja untuk mendapatkan upah seminggu yang lalu $(d$ work 4 pay $=0)$, sesuai dengan pengaturan yang dilakukan oleh Angrist dan Evans (1996; 1998).

\subsection{Uji Akurasi Instrumen}

Khandker, et al. (2010, hal. 87) menyatakan bahwa pendekatan IV melibatkan proses pencarian variabel instrumen yang memiliki korelasi yang baik dengan variabel endogen (program/treatment) tetapi tidak berkorelasi dengan karakteristik yang tidak teramati yang mempengaruhi variabel dependen (outcome). Dengan kata lain variabel instrumen yang dipilih tidak memiliki pengaruh yang signifikan secara statistik terhadap variabel dependen. Tabel 6 menunjukkan bahwa dari dua kelompok variabel instrumen yang dipilih, tidak ada satu kelompok pun yang memiliki pengaruh yang signifikan secara statistik terhadap variabel dependen, baik dwork4pay maupun workhour.

Korelasi dari variabel instrumen dengan variabel endogen dapat terlihat dalam first stage 
Tabel 9 Hasil estimasi model dengan menggunakan variabel dependen/outcome dwork4pay

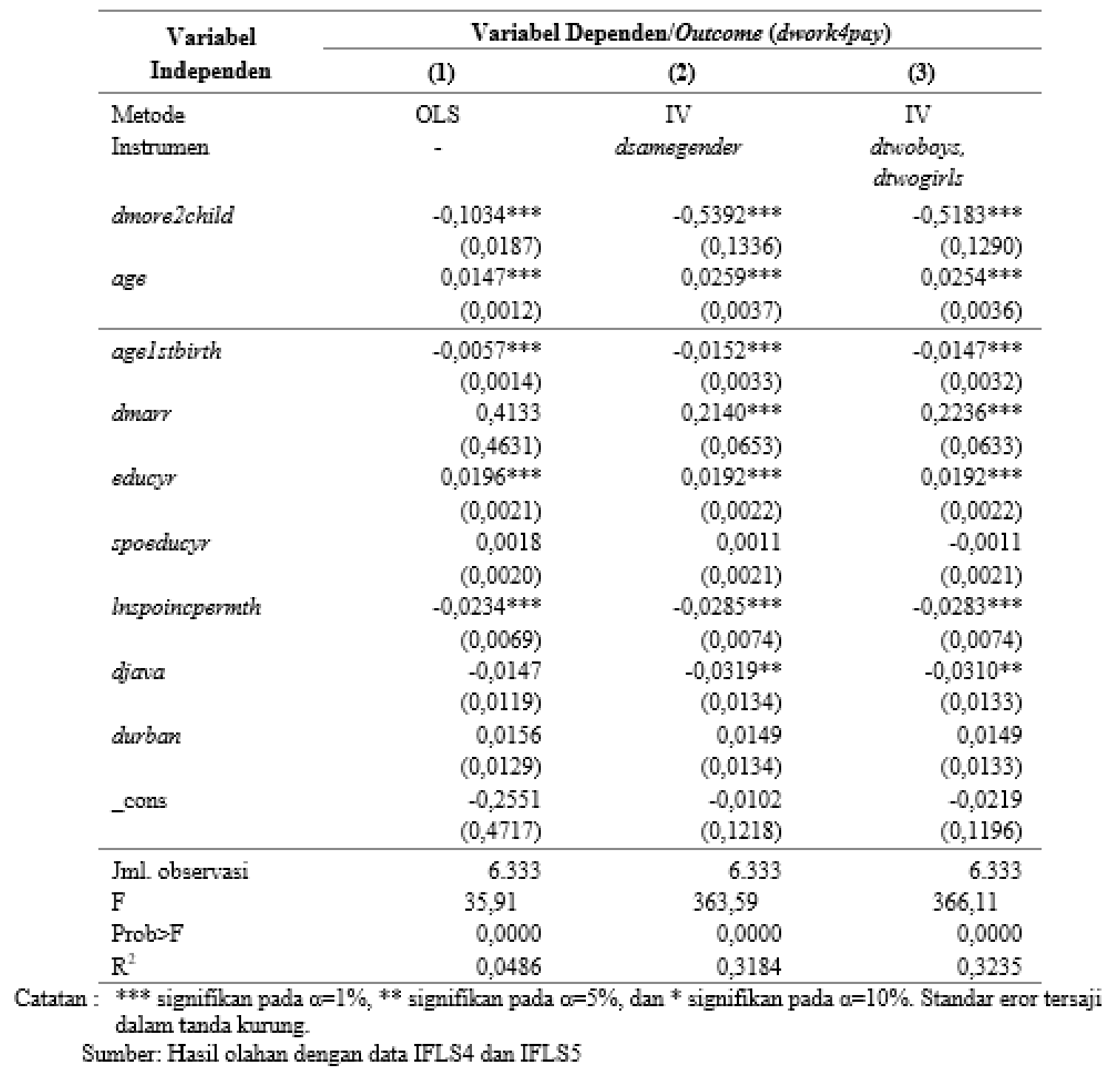

regression yang tersaji dalam Tabel 7. Dari tabel tersebut, terlihat bahwa variabel instrumen yang dipilih sudah memiliki korelasi yang baik dengan variabel endogen. Dengan demikian, variabel instrumen yang dipilih dapat dikatakan baik karena telah memenuhi dua persyaratan, yaitu variabel instrumen harus tidak berkorelasi dengan tingkat kesalahan $u$, atau dapat dilihat dari nilai statistik prob $>$ F yang tidak signifikan ketika variabel instrumen diregresikan terhadap variabel dependen, dan terdapat korelasi antara variabel instrumen dengan variabel endogen.

Pengujian setelah estimasi IV pada Tabel 8 menunjukkan bahwa variabel dmore 2 child memang bersifat endogen. Hal ini terlihat dari pengujian endogenitas $\mathrm{Wu}-H a u s m a n$, di mana nilai $\mathrm{p}$ pada masing-masing model kurang dari nilai $\alpha=5 \%$ yang berarti berhasil menolak H0: variables are exogenous. Untuk pengujian weak identification, nilai masing-masing $F$ test untuk excluded instruments lebih besar dari Stock-Yogo critical values untuk semua tingkat signifikansi, sehingga dapat dikatakan bahwa variabel instrumen yang digunakan sudah memiliki korelasi yang kuat terhadap variabel endogen.

Untuk mengetahui bahwa parameter dapat teridentifikasi dengan baik dapat merujuk pada hasil underidentification test. Nilai p-value pada masing-masing model yang lebih kecil dari $\alpha=5 \%$ menunjukkan bahwa model telah teridentifikasi, yaitu bahwa instrumen sudah relevan dan memiliki korelasi dengan variabel endogen. Selanjutnya adalah overidentification test yang dilakukan untuk memastikan bahwa variabel instrumen yang digunakan sudah valid dengan melihat statistik Hansen J. Nilai p-value pada masing-masing model yang lebih besar dari $\alpha=5 \%$ menunjukkan bahwa variabel instrumen yang 
Tabel 10 Hasil estimasi model dengan menggunakan variabel dependen/outcome workhour

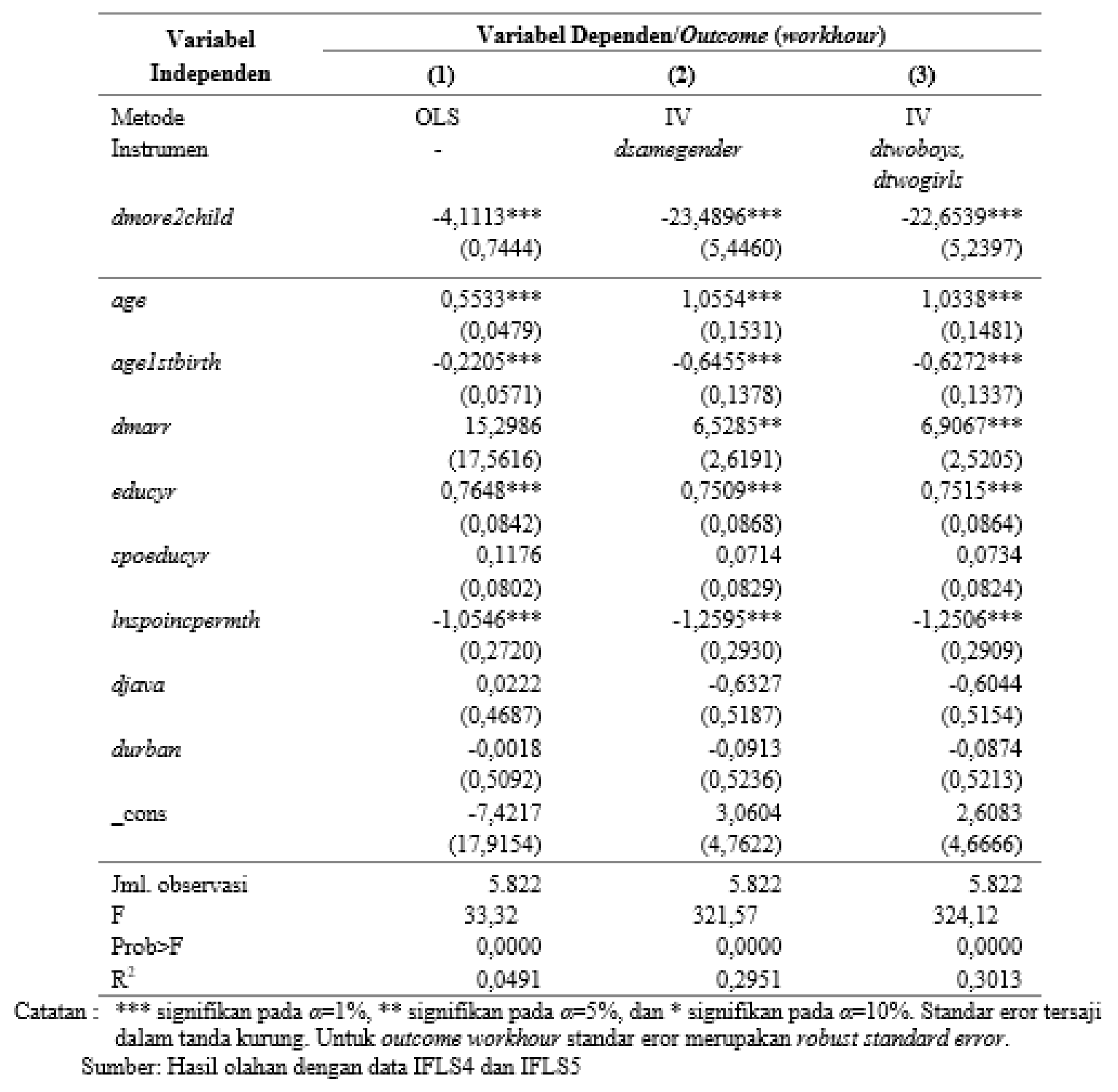

digunakan sudah valid, yaitu tidak berkorelasi dengan residual/error term dan telah dikecualikan dari estimasi model. Untuk uji heteroskedastisitas dalam konteks IV, nilai $p$-value untuk semua model lebih kecil dari $\alpha=5 \%$ yang berarti menolak $\mathrm{H} 0$ : disturbance is homoskedastic, sehingga pada model yang digunakan terdapat permasalahan heteroskedastisitas.

\subsection{Uji Hipotesis}

Permasalahan endogenitas pada fertilitas dengan pendekatan jumlah anak membuat estimasi dengan metode OLS menjadi tidak konsisten. Hal ini dapat dilihat pada Tabel 9 dan Tabel 10, di mana baik pada model dengan variabel dependen $d$ work4pay maupun workhour memberikan hasil estimasi yang signifikan pada variabel penjelasnya, tetapi memiliki koefisien determinasi $\left(\mathrm{r}^{2}\right)$ yang rendah.
Selain itu, terlihat bahwa metode OLS memberikan hasil estimasi yang lebih kecil dibandingkan dengan metode IV. Metode IV sendiri juga memberikan hasil estimasi yang hampir serupa baik pada model yang menggunakan instrumen dsamegender maupun instrumen dtwoboys dan dtwogirls. Hal ini dapat menunjukkan ketahanan (robustness) yang baik pada hasil estimasi yang diperoleh, di mana koefisien dari variabel-variabelnya memiliki besaran yang tidak berbeda jauh dan arah pengaruh yang sama.

Hasil estimasi baik dari metode OLS maupun metode IV pada Tabel 9 dan Tabel 10 menunjukkan bahwa fertilitas dengan pendekatan jumlah anak berpengaruh terhadap penawaran tenaga kerja perempuan yang dilihat dari partisipasi dalam angkatan kerja dan jumlah jam kerjanya karena didukung bahkan sampai derajat kepercayaan 
99 persen. Adapun arah dari pengaruh fertilitas tersebut adalah negatif yang berarti terjadi penurunan dalam penawaran tenaga kerja perempuan.

\subsection{Pembahasan}

Hasil estimasi pada first stage regression pada Tabel 7 menunjukkan bahwa perempuan dengan dua anak pertama berjenis kelamin sama akan memiliki sekitar 13 persen kemungkinan untuk menambah anak ketiga pada model tersebut, ceteris paribus. Apabila jenis kelamin dua anak pertama tersebut dirinci, maka perempuan dengan dua anak pertama berjenis kelamin laki-laki akan memiliki kemungkinan lebih besar, yaitu sekitar 16 persen untuk menambah anak ketiga dibandingkan dengan kemungkinan 10 persen untuk perempuan dengan dua anak pertama berjenis kelamin perempuan, ceteris paribus.

Penelitian ini menggunakan komposisi jenis kelamin anak untuk mengestimasi pengaruh dari variabel dmore2child (memiliki lebih dari dua anak) terhadap penawaran kerja dari perempuan. Tabel 9 dan Tabel 10 menunjukkan bahwa dampak adanya anak ketiga akan mengurangi probabilitas untuk bekerja bagi perempuan sebesar 10,34 persen dan menyebabkan jam kerja berkurang sekitar 4 jam per minggunya untuk hasil estimasi dengan metode OLS. Untuk hasil estimasi dengan metode IV, dampak adanya anak ketiga akan mengurangi 52-54 persen probabilitas bekerja dan sekitar 23 jam kerja per minggunya. Selain itu, dapat dilihat juga bahwa pendapatan suami memiliki dampak negatif dan signifikan terhadap penawaran tenaga kerja perempuan, di mana perempuan akan mengurangi penawaran tenaga kerjanya ketika pendapatan suaminya tinggi. Sedangkan, tingkat pendidikan dan status perkawinannya memiliki dampak positif dan signifikan penawaran tenaga kerja perempuan tersebut. Hal ini menunjukkan bahwa tingkat pendidikan yang tinggi dan status perkawinan menjadi pendorong perempuan untuk masuk dalam pasar kerja.

\section{Penutup}

\subsection{Simpulan}

Penelitian ini menunjukkan pengaruh fertilitas perempuan terhadap penawaran kerja di Indonesia dengan menggunakan data IFLS dan metode estimasi variabel instrumental (instrumental
variable/IV) yang pertama diperkenalkan oleh Angrist dan Evans (1996; 1998) yang dilakukan di Amerika Serikat. Penelitian ini menunjukkan bagaimana preferensi orang tua terkait dengan jenis kelamin anak yang berbeda sebagai identifikasi terhadap fertilitas terhadap partisipasi perempuan dalam pasar tenaga kerja. Hasil penelitian menunjukkan bahwa fertilitas dengan pendekatan jumlah anak yang dimiliki yang kemudian diinstrumenkan dengan melihat jenis kelamin anak tersebut memberikan dampak penurunan pada penawaran tenaga kerja perempuan. Besaran pengaruh pada kelompok usia kerja adalah terdapat penurunan partisipasi kerja sekitar 52-54 persen dan penurunan jam kerja keseluruhan sekitar 23 $\mathrm{jam} / \mathrm{minggu}$.

\subsection{Implikasi}

Penelitian ini menunjukkan bahwa terdapat penurunan penawaran tenaga kerja perempuan yang dilihat dari partisipasi dalam angkatan kerja dan jam kerja keseluruhan terhadap keputusannya untuk menambah jumlah anak. Dalam empat dekade terakhir, Total Fertility Rate (TFR) di Indonesia telah turun cukup signifikan, dari 5,61 menjadi 2,60. Hal ini merupakan salah satu bukti nyata dari keberhasilan program Keluarga Berencana (KB) di Indonesia yang dicanangkan pada tahun 1970. Hal ini diikuti dengan partisipasi perempuan dalam angkatan kerja meningkat dari sekitar 30 persen di tahun 1980-an menjadi sekitar 50 persen di tahun 2000 -an. Turunnya fertilitas diharapkan dapat meningkatkan akses perempuan di bidang ekonomi, sehingga dapat meningkatkan kesejahteraan keluarga. Selain itu, perlu adanya pembentukan dan pengembangan model-model pemberdayaan masyarakat, terutama di bidang ekonomi untuk meningkatkan produktivitas ekonomi perempuan, antara lain melalui pengembangan industri rumah tangga untuk menguatkan perempuan pelaku usaha.

\section{DAFTAR PUSTAKA}

Aguero, J. M., \& Marks, M. S. (2008). Motherhood and Female Labor Force Participation: Evidence from Infertility Shocks. The American Economic Review, Vol. 98, No. 2, 500-504.

Angrist, J. D., \& Evans, W. N. (1996). Children and Their Parent's Labor Supply: Evidence from Exogenous Variation in Family Size. NBER 
Working Paper No 5778

Angrist, J. D., \& Evans, W. N. (1998). Children and Their Parent's Labor Supply: Evidence from Exogenous Variation in Family Size. The American Economic Review, Vol. 88, No. 3, 450-477.

Badan Pusat Statistik. (2010). Keadaan Angkatan Kerja di Indonesia Februari 2010. Jakarta: Badan Pusat Statistik.

Badan Pusat Statistik. (2011). Keadaan Angkatan

Kerja di Indonesia Agustus 2011. Jakarta: Badan Pusat Statistik.

Badan Pusat Statistik. (2012). Keadaan Angkatan Kerja di Indonesia Februari 2012. Jakarta: Badan Pusat Statistik.

Badan Pusat Statistik. (2013). Keadaan Angkatan

Kerja di Indonesia Februari 2013. Jakarta: Badan Pusat Statistik.

Badan Pusat Statistik. (2014). Keadaan Angkatan

Kerja di Indonesia Februari 2014. Jakarta: Badan Pusat Statistik.

Badan Pusat Statistik. (2015). Keadaan Angkatan Kerja di Indonesia Februari 2015. Jakarta: Badan Pusat Statistik.

Badan Pusat Statistik. (2015). Statistik 70 Tahun Indonesia Merdeka. Jakarta: Badan Pusat Statistik.

Badan Pusat Statistik. (2016). Keadaan Angkatan

Kerja di Indonesia Februari 2016. Jakarta: Badan Pusat Statistik.

Becker, G. S. (1960). An Economic Analysis of

Fertility. Dalam U.-N. Bureau, Demographic and Economic Change in Developed Countries (hal. 209-240). New York: Columbia University Press. Becker, G. S. (1965). A Theory of the Allocation of Time. The Economic Journal, Vol. 75, No. 299, 493-517.

Bhalla, S. S., \& Kaur, R. (2011). Labour Force Participation of Women in India: Some Facts, Some Queries. Asia Research Centre Working Paper 40.

Bloom, D. E., Canning, D., Fink, G., \& Finlay, J. E. (2009). Fertility, female labor force participation, and the demographic dividend. Journal of Economic Growth 14, 79-101.

Brewster, K. L., \& Rindfuss, R. R. (2000). Fertility and Women's Employment in Industrialized Nations. Annual Review of Sociology, Vol. 26, 271-296.

Cramer, J. C. (1980). Fertility and Female Employment: Problems of Causal Direction. American Sosiological Review, 167-190.
Cruces, G., \& Galiani, S. (2007). Fertility and female labor supply in Latin America: New causal evidence. Labour Economics 14, 565-573.

Daouli, J., Demoussis, M., \& Giannakopoulos, N. (2009). Sibling-sex composition and its effects on fertility and labor supply of Greek mothers. Economics Letters, 189-191.

Dewi, P. M. (2012). Partisipasi Tenaga Kerja Perempuan dalam Meningkatkan Pendapatan Keluarga. Jurnal Ekonomi Kuantitatif terapan, Vol. 5, No. 2, 119-124.

Ehrenberg, R. G., \& Smith, R. S. (2012). Modern Labor Economics: Theory and Public Policy (11th ed.). Boston: Pearson Education, Inc.

Engelhardt, H., Kogel, T., \& Prskawetz, A. (2004). Fertility and women's employment reconsidered: A macro-level time-series analysis for developed countries, 1960-2000. Population Studies, Vol. 58, No. 1, 109-120.

Gregory, P. R. (1982). Fertility and Labor Force Participation in the Soviet Union and Eastern Europe. The Review of Economics and Statistics, Vol. 64, No. 1, 18-31.

Gronau, R. (1976). Leisure, Home Production and Work - The Theory of the Allocation of Time Revisited. NBER Working Paper No. 137.

Gujarati, D. N., \& Porter, D. C. (2009). Basics Econometrics (5th ed.). New York: McGraw-Hill/ Irwin.

Hakim, L. (2011). Perkembangan Tenaga Kerja Wanita di Sektor Informal: Hasil Analisa dan Proxy Data Sensus Penduduk. Among Makarti, Vol. 4, No. 7, 20-32.

Khandker, S. R., Koolwal, G. B., \& Samad, H.A. (2010). Handbook on Impact Evaluation: Quantitative Methods and Practices. Washington, D.C.: The World Bank.

Lavy, V., \& Zablotsky, A. (2011). Mother's Schooling and Fertility under Low Female Labor Force Participation: Evidence from a Natural Experiment. NBER Working Paper No 16856.

Lee, B. S., \& McElwain, A. M. (1985). An Empirical Investigation of Female Labor-Force Participation, Fertility, Age at Marriage, and Wages in Korea. The Journal of Developing Areas, Vol. 19, No. 4, 483-500.

Lee, B. S., Jang, S., \& Sarkar, J. (2008). Women's labor force participation and marriage: The Case of Korea. Journal of Asian Economics 19, 138154. 
Mishra, V., \& Smyth, R. (2010). Female labor force participation and total fertility rates in the OECD: New evidence from panel cointegration and Granger causality testing. Journal of Economics and Business 62, 48-64.

Ogawa, K., \& Akter, M. (2007). Female Labor Force Participation in Indonesia. Journal of International Cooperation Studies, Vol. 14, No. 3, 71-108.

Park, S.-B. (1974). On Indirect Least Squares Estimation of a Simultaneous Equation System. The Canadian Journal of Statistics / La Revue Canadienne de Statistique, Vol. 2, No. 1, 75-82. Pemerintah Republik Indonesia. (2003). Undang-undang Nomor 13 Tahun 2003 tentang Ketenagakerjaan. Jakarta: Kementerian Hukum dan Hak Asasi Manusia Republik Indonesia.

Siah, A. K., \& Lee, G. H. (2015). Female labour force participation, infant mortality and fertility in Malaysia. Journal of the Asia Pacific Economy, Vol. 20, No.4, 613-629.

Strauss, J., Witoelar, F., \& Sikoki, B. (2016). The Fifth Wave of the Indonesia Family Life Survey (IFLS5): Overview and Field Report. RAND Working Paper WR-1143/1-NIA/NICHD.

Strauss, J., Witoelar, F., Sikoki, B., \& Wattie, A. (2009). The Fourth Wave of the Indonesia Family Life Survey (IFLS4): Overview and Field Report. RAND Working Paper WR-675/1-NIA/NICHD. Tjaja, R. P. (2000). Wanita Bekerja dan Implikasi Sosial. Naskah No. 20, 1-6.

Widarti, D. (1998). Determinants of Labour Force Participation by Married Women: The Case of Jakarta. Bulletin of Indonesian Economic Studies, 93-120.

Wooldridge, J. M. (2002). Econometric analysis of cross section and panel data. Cambridge: The Massachusetts Institute of Technology Press. Yamada, T., \& Yamada, T. (1984). Part-time Employment of Married Women and Fertility in Urban Japan. NBER Working Paper No. 1474. 